\title{
CHANGES IN GROWTH AND CHEMICAL DEFENCES UPON DEFOLIATION IN MAIZE
}

\author{
Hugo G. Collantes, Ernesto Gianoli and Hermann M. Niemeyer* \\ Departamento de Ciencias Ecológicas, Facultad de Ciencias, Universidad de Chile, Casilla 653, \\ Santiago, Chile
}

(Received in revised form 8 April 1998)

\begin{abstract}
Key Word Index-Zea mays; Poaceae; maize; defoliation; chemical defence; hydroxamic
\end{abstract} acids; DIMBOA.

\begin{abstract}
The effect of defoliation on growth and on levels and allocation patterns of hydroxamic acids $(\mathrm{Hx})$ in maize seedlings was evaluated 6 days after treatment. No significant differences were found between defoliated and nondefoliated plants for the $\mathrm{Hx}$ concentration, relative $\mathrm{Hx}$ content and $\mathrm{Hx}$-aglucone to $\mathrm{Hx}$ glucoside ratio in shoots, roots and root exudates, with the exception of Hx concentration in shoots, which decreased upon defoliation. However, growth of defoliated seedlings was considerably higher than that of nondefoliated ones. These results indicate that maize responds to defoliation by allocating its resources mainly to growth rather than to defence. Since previous work described the opposite strategy in rye, responses to defoliation in both species are discussed in relation to current theories of plant defence. (C) 1998 Elsevier Science Ltd. All rights reserved
\end{abstract}

\section{INTRODUCTION}

Hydroxamic acids (Hx) present in wild and cultivated Poaceae $[1,2]$ play a role in plant resistance against herbivores and pathogens [3-5] and in allelopathy [6,7]. Hx occur mainly as glucosides which are converted to the more active aglucones [8] by enzymatic hydrolysis upon tissue damage [9].

Research on plant responses induced by insect feeding or wounding has focused mainly on the increase in concentration of defensive compounds [10]. The induction of $\mathrm{Hx}$ after insect attack or localised artificial damage has been widely described [11-15], while their induction upon defoliation, a process analogous to grazing or harvesting practices, has been only recently reported $[16,17]$. Collantes et al. [17] showed that rye (Secale cereale L.) seedlings responded to defoliation not by an increase in $\mathrm{Hx}$ concentration of aerial tissue but by: (i) an increase of exudation of $\mathrm{Hx}$ by the roots, (ii) increased relative allocation of $\mathrm{Hx}$ to roots and root exudates and (iii) transformation of Hx-glucosides into more toxic aglucones. The present work addresses the induction of $\mathrm{Hx}$ upon defoliation in maize (Zea mays L.) and compares it with the patterns found in rye [17].

*Author to whom correspondence should be addressed.

\section{RESULTS AND DISCUSSION}

\section{Quantification of DIMBOA in maize seedlings}

The most abundant hydroxamic acid in maize is 2- $\beta$ - $O$-D-glucopyranosyl-4-hydroxy-7-methoxy-1,4benzoxazin-3-one (DIMBOA-Glc) [1]. Both DIMBOA-Glc and its aglucone were found in shoots and roots of maize seedlings, while in root exudates only the aglucone was found, in agreement with a previous report by Pérez and Ormeño [6]. The concentration of total hydroxamic acids in both nondefoliated and defoliated seedlings was considerably higher in shoots than in roots and in roots than in root exudates (Table 1). The same patterns were found for $\mathrm{Hx}$ in rye under the same experimental conditions [17].

\section{Induction of $H X$ upon defoliation}

The induction of $\mathrm{Hx}$ upon defoliation was evaluated by assessing the following parameters: (i) $\mathrm{Hx}$ concentration $(\mathrm{mmol} / \mathrm{kg}$ fresh-weight) in shoots, roots and root exudates (considered as the $\mathrm{Hx}$ content of root exudates divided by the fresh weight of roots), (ii) relative $\mathrm{Hx}$ content ( $\%$ of $\mathrm{Hx}$ content in the whole plant) in shoots, roots and root exudates and (iii) $\mathrm{Hx}$ aglucone/glucoside ratio in shoots and roots. Results for defoliated and nondefoliated seedlings were compared by a one-way ANOVA. 
Table 1. Hydroxamic acids concentration $(\mathrm{mmol} / \mathrm{kg}$ freshweight) in maize seedlings \pm S.E.

\begin{tabular}{lccc}
\hline & Nondefoliated & Defoliated & $P$-value* \\
\hline Shoot & $26.5 \pm 1.2$ & $12.1 \pm 0.6$ & $<0.0001$ \\
Root & $1.70 \pm 0.21$ & $1.28 \pm 0.09$ & 0.064 \\
Exudates & $0.03 \pm 0.01$ & $0.02 \pm 0.01$ & 0.39 \\
\hline
\end{tabular}

*One-way ANOVA.

Nonsignificant differences were found between defoliated and nondefoliated seedlings for all assessed parameters except for the $\mathrm{Hx}$ concentration in shoots (Tables 1-3). Defoliated seedlings showed lower concentrations of $\mathrm{Hx}$ than nondefoliated ones. These results indicate that $\mathrm{Hx}$ in maize is not induced by defoliation, contrary to what occurs with $\mathrm{Hx}$ in rye under the same experimental conditions $[16,17]$.

\section{Compensatory growth of defoliated seedlings}

Maize seedlings were weighed before extraction. Shoot biomass $(\mathrm{mg})$ of defoliated seedlings $(747.78 \pm 36.13)$ was significantly higher $(P<0.0001$, one-way ANOVA) than that of nondefoliated ones $(287.55 \pm 20.08)$. Thus, while showing no $\mathrm{Hx}$ induction, maize seedlings subjected to defoliation experienced overcompensatory growth (sensu Paige and Whitham [18]). On the contrary, $\mathrm{Hx}$ induction was found in defoliated rye seedlings, which showed in addition subcompensatory growth, under the same experimental conditions [17].

The predominant investment of rye in chemical defence and of maize in compensatory growth as a consequence of defoliation may be attributed to the $C_{3}$ nature of rye and $C_{4}$ nature of maize [19]. Thus, on one hand $\mathrm{C}_{4}$ plants are poorer food sources for herbivores than $\mathrm{C}_{3}$ plants and hence should invest less resources in defence [20] and, on the other, according to the optimal defence theory, given a limited amount of resources, plants tend not to invest simultaneously in alternative functions (e.g. growth and defence) [21-23]. Moreover, since maize is a crop species which has been largely modified by breeding in contrast to rye [24], the overcompensatory growth and lack of induction of chemical defences of maize upon defoliation may be reflecting past selection aiming at increased crops yields. In addition, given that phytochemical induction is a widespread phenomenon in wild plants [10], our

Table 2. Hydroxamic acids relative content (\% of whole plant content) in maize seedlings \pm S.E.

\begin{tabular}{lccc}
\hline & Nondefoliated & Defoliated & $P$-value* \\
\hline Shoot & $80.8 \pm 2.3$ & $82.9 \pm 0.9$ & 0.37 \\
Root & $18.7 \pm 2.4$ & $16.9 \pm 0.9$ & 0.47 \\
Exudates & $0.41 \pm 0.10$ & $0.23 \pm 0.03$ & 0.067 \\
\hline
\end{tabular}

*One-way ANOVA.
Table 3. Hydroxamic acid aglucone to glucoside ratio in maize seedlings \pm S.E.

\begin{tabular}{lccc}
\hline & Nondefoliated & Defoliated & $P$-value* \\
\hline Shoot & $0.37 \pm 0.08$ & $0.49 \pm 0.10$ & 0.36 \\
Root & $0.22 \pm 0.07$ & $0.34 \pm 0.01$ & 0.089 \\
\hline
\end{tabular}

*One-way ANOVA.

results may also reflect the erosion of genetic variability in maize through breeding [25].

\section{EXPERIMENTAL}

\section{Plant material}

Seeds of $Z$. mays cv. T55s from Tracy Seed, Chile, were germinated in individual plastic pots $(100 \mathrm{ml})$ filled with sterilised sand (Anasac). Seedlings were kept in a room at $25 \pm 3^{\circ} \mathrm{C}$ and $16: 8 \mathrm{~h}$ light regime and irrigated with a nutritious solution (Anasac) containing N:P:K (6:4:3) and micronutrients. Half of the seedlings were defoliated 6 days after germination by cutting the plants just above the coleoptile. Nondefoliated and defoliated seedlings (seven seedlings per treatment) were evaluated 6 days after sowing and defoliation, respectively.

\section{Extracts for analysis}

Seedlings were carefully drawn from the sand to avoid root damage. Roots were washed with distilled water directly onto the pots to remove sand particles. Seedlings were weighed and then shoots and roots were separated and immediately macerated using mortar and pestle with $c a .300 \mathrm{mg}$ sea sand in $1 \mathrm{ml} 0.1 \mathrm{M}$ glycine- $\mathrm{HCl}$ buffer $\mathrm{pH} 2$. Plant parts were macerated immediately in order to avoid spurious conversion of $\mathrm{Hx}$ glucosides into aglucones due to the scission of the plant. Consequently, the weight of tissues was not directly determined but estimated from linear regressions of total plant weight vs shoot weight $\left(R^{2}=0.98\right.$ for nondefoliated and $R^{2}=0.89$ for defoliated) and total plant weight vs root weight $\left(R^{2}=0.99\right.$ for nondefoliated and $R^{2}=0.96$ for defoliated). The sand in the pots was washed with $100 \mathrm{ml}$ distilled water to obtain root exudates. The washing solution was evaporated to dryness under vacuum at $45^{\circ} \mathrm{C}$ and the dry residue extracted with $1 \mathrm{ml} n$-BuOH. All extracts were centrifuged at $10,400 \mathrm{~g}$ for $15 \mathrm{~min}$ and the supernatants stored in a freezer until analysis.

\section{Chromatography}

A $100 \mathrm{ml}$ aliquot of each extract was directly injected into a HPLC fitted with an RP-100 LiChrospher-C18 column (5 mm i.d., Merck). Conditions were constant solvent flow $\left(1.5 \mathrm{ml} \mathrm{min}^{-1}\right)$, the following linear gradients between solvents $\mathrm{A}(\mathrm{MeOH})$ and $\mathrm{B}(0.5 \mathrm{ml} 85 \%$ 
$\mathrm{H}_{3} \mathrm{PO}_{4}$ in $11 \mathrm{H}_{2} \mathrm{O}$ ): $0-9 \min 30 \% \quad \mathrm{~A}, \quad 9-11 \mathrm{~min}$ $100 \% \mathrm{~A}, 11-15 \mathrm{~min} 30 \% \mathrm{~A}$ and detection at $263 \mathrm{~nm}$. Both DIMBOA-glucoside and its aglucone were analysed. Only the aglucone was found in root exudates. Retention times for aq. extracts were $3.7 \pm 0.1$ and $4.8 \pm 0.1 \mathrm{~min}$ for DIMBOA-glucoside and DIMBOA aglucone, respectively, and $1.9 \pm 0.1 \mathrm{~min}$ for the DIMBOA aglucone in $n$ $\mathrm{BuOH}$. Identity of the peaks was confirmed by coinjection of standards dissolved in water and $n$ $\mathrm{BuOH}$, respectively.

Acknowledgements-The financial support of the International Program in the Chemical Sciences (IPICS) at Uppsala University, the Presidential Chair in Sciences awarded to HMN and the Latin American Network for Research on Bioactive Natural Compounds (LANBIO) for a fellowship to H. G. C. during the development of this work, are gratefully acknowledged.

\section{REFERENCES}

1. Niemeyer, H. M., Phytochemistry, 1988, 27, 3349.

2. Niemeyer, H. M., Euphytica, 1988, 37, 289.

3. Bergvinson, D. J., Hamilton, R. I. and Arnason, J. T., Journal of Chemical Ecology, 1995, 21, 343.

4. Niemeyer, H. M. and Pérez, F. J., in Allelopathy. Organisms, Processes and Applications, ACS Symposium Series 582, eds. Inderjit, K. M. M. Dakshini and F. A. Einhelling. Washington, DC, 1995, p. 260.

5. Weibull, J. and Niemeyer, H. M., Physiological and Molecular Plant Pathology, 1995, 47, 201.

6. Pérez, F. J. and Ormeño-Nuñez, J., Weed Research, 1993, 33, 115.

7. Mwaja, V. N., Masiunas, J. B. and Weston, L. A., Journal of Chemical Ecology, 1995, 21, 81.

8. Corcuera, L. J., Queirolo, C. B. and Argandoña, V. H., Experientia, 1985, 41, 514.

9. Hofman, J. and Hofmanová, O., Phytochemistry, 1971, 10, 1441.
10. Tallamy, D. W. and Raupp, M. J., Phytochemical Induction by Herbivores. John Wiley and Sons, New York, 1991.

11. Gutiérrez, C., Castañera, P. and Torres, V., Annals of Applied Biology, 1988, 113, 447.

12. Niemeyer, H. M., Pesel, E., Copaja, S. V., Bravo, H. R., Franke, S. and Francke, W., Phytochemistry, 1989, 28, 447.

13. Morse, S., Wratten, S. D., Edwards, P. J. and Niemeyer, H. M., Annals of Applied Biology, 1991, 119, 239.

14. Gianoli, E. and Niemeyer, H. M., Journal of Chemical Ecology, 1997, 23, 2695.

15. Gianoli, E. and Niemeyer, H. M., Chemoecology, 1998 (in press).

16. Collantes, H. G., Gianoli, E. and Niemeyer, H. M., Environmental and Experimental Botany, 1998, 38, 231.

17. Collantes, H. G., Gianoli, E. and Niemeyer, H. M., Journal of Chemical Ecology (submitted).

18. Paige, K. N. and Whitham, T. G., American Naturalist, 1987, 129, 407.

19. Raven, P. H., Evert, R. F. and Eichhorn, S. E., Biology of Plants. Worth Publishers, New York, 1986.

20. Caswell, H., Reed, F., Stephenson, S. N. and Werner, P. A., American Naturalist, 1973, 107, 465.

21. Rhoades, D., in Herbivores: Their Interaction with Secondary Plant Metabolites, eds. G. A. Rosenthal and D. H. Janzen. Academic Press, San Diego, 1979, p. 3.

22. Herms, D. A. and Mattson, W. J., Quarterly Reviews in Biology, 1992, 67, 283.

23. Zangerl, A. R. and Bazzaz, F. A., in Plant Resistance to Herbivores and Pathogens. Ecology, Evolution and Genetics, eds. R. S Fritz and E. L. Simms. The University of Chicago Press, London, 1992, p. 363.

24. Simmonds, N. W., Evolution of Crop Plants. Longman Scientific and Technical, Hong Kong, 1986.

25. Harlan, J. R., Crop Science, 1976, 16, 329. 